UDC $82 ' 282$

DOI: $10.17223 / 19986645 / 66 / 14$

\author{
Mariana S. Sargsyan ${ }^{1}$, Evgeniya V. Zimina ${ }^{2}$ \\ ${ }^{1}$ Yerevan State University (Yerevan, Armenia) \\ E-mail:marianasargsyan@ysu.am / mariana.sargsyan80@gmail.com \\ ${ }^{2}$ Kostroma State University (Kostroma, Russian Federation) \\ E-mail:ezimina@rambler.ru
}

\title{
SCOTS IN CONTEMPORARY PROSE AND POETRY: ISSUES AND CONTROVERSIES
}

\begin{abstract}
The paper aims to represent the relevant issues concerning the status of Scots and its use in literature. It also covers a range of controversial interpretations concerning the status of Scots and its reputation. By drawing analogies and highlighting the differences, the paper seeks to reveal the range of shared and unshared attitudes towards Scots and its significance in the literary discourse. Our study shows that Scots is not regarded as a tool to be used to fight for a political cause, neither it is a means through which people identify themselves. In contemporary writing Scots performs a huge role in creating new meanings and associations, enriching the text with connotations and imparting special meaning to the text.

Key words: Scots, status, cultural and language identity, pluralism, contemporary Scottish prose and poetry.
\end{abstract}

\section{Introduction}

There is no denying the fact that the linguistic situation in Scotland is not a simple one and there is no clear prognosis what the situation will be in a ten- or twenty-year perspective. However, one point is obvious - there is no unique approach to the status of Scots shared by all. Looking back into the history of the problem, we learn that the roots of the controversial attitudes towards Scots and its status rest in the indisputable close relation between Scots (formed on the northern dialects) and English (developed on the east-central and southern dialects of Middle English). As a result of Scotland's acquisition of political and cultural independence in the 15th century, Scots started its functioning as an independent language and it was widely used not only as a means of everyday communication, but also in official settings. However, this period was not to last long, as English gradually supplanted it from the official sphere and the culmination was the Treaty of Union (1707), which resulted in equating the status of Scots to that of a dialect. However, later in the 18th century, the literary tradition in Scots revived, and this process continues till our days. The Treaty of 1707 sparked a reactionary movement led by a group of poets (Alan Ramsay, Robert Fergusson and Robert Burns), which is known as Vernacular Revival in Scots. This process was further increased in the 19th century when novelists (Walter Scott, Hogg, Robert Louis Stevenson) joined this movement by extensively in- 
troducing Scots-speaking characters in their fictional works and the combination of English and Scots in the works of this period managed to bring the Scots language and Scottish literature to the attention of the international community. In the 20th century, a new radical renaissance of Scots was pioneered by Hugh MacDiarmid, whose contribution to the strengthening of the position of Scots as a literary language cannot be underestimated. MacDiarmid was especially passionate in creating literary Scots by means of the synthesis of the dialects. The language of poetry, known as Lallance, was an artificially created language which did not reflect the spoken language, thus it was complicated and not understandable for all. Later in the 20th century, writing in Scots became popular but many of the writers rejected the language of MacDiarmid, and instead returned to the language of Fergusson and Burns. Many writers created their works based on the city dialects which were more understandable and did not require special glossaries to translate them.

Contemporary Scottish dialects are not homogeneous, and the problem of the status of Scots is not yet solved. There are controversial attitudes among the scholars whether it can gain the status of an independent language or not, since, for a part of scholars, Scots remains a language which should not be described as an independent language, but rather a corrupted version of English which needs to be corrected [1]. This attitude accounts for the absence of the Standard Scottish, standardized orthography, and a huge number of English borrowings. Comparing the situation with Scots with that of Gaelic, it is understandable that although the number of Gaelic speakers $(1.1 \%)$ is less than that of Scots $(35 \%)$, the situation with the Gaelic language is much more favourable, in view of the fact that it is unarguably a separate language with specific grammar and vocabulary.

The promotion of Scots as an independent language remains one of the political priorities of the Scottish National Party, which initiated a number of actions towards the recognition of Scots as an important element of the cultural heritage of Scotland and also its recognition as one of the three historically local languages (along with Gaelic and English) of Scotland. One of the major players in the promotion and the support for the development of Scots is the Creative Scotland, a state organization, which provides support to the fields of art, literature, cinema, etc.

Like Scots with all the pluralities of forms and doubts concerning its status, the attitudes towards Scots, its use and the sphere of its influence as well as its reputation as a language are non-homogeneous. Thus, by drawing analogies and highlighting the differences, the paper seeks to reveal the range of shared and unshared attitudes towards Scots and its significance in the literary discourse. We will discuss in what ways Scots contributes to the richness of the work by adding new dimensions to the text, or what the basic arguments of those who claim that Scots belittles the literary value of the work are. To discuss the problem in the historical context, the research incorporates contemporary texts and poetry with several references to early 20 th-century writing. 


\section{Poets on Scots: Discussing Language Through Poetry}

In the context of the linguistic and cultural pluralism, contemporary Scottish literature, particularly poetry, has not remained indifferent to the problem of language. Discussing a range of poems by contemporary writers, it becomes clear that identity and language continue to be a central topic for contemporary Scottish literature. However, the formulation of the problem has undergone changes: language and identity in contemporary literature are no longer associated with political nationalism which was the main ideology and the driving force at the beginning of the 20th century. Language is not only a mere means of communication, it not only reflects the nation's history and culture, but it is what makes one feel a part of the community, it cultivates and at the same time questions the sense of belonging. Thus, the problem of language and identity in contemporary poetry has somewhat changed its framework. As noted by Roderick Watson "for contemporary literature if identity is an issue, it is more likely to be framed in the context of personal, existential, political or sexual being" [2]. Thus, in the context of the linguistic and cultural pluralism of Scotland, the question that naturally arises is in what ways the writer's individual language or voice is brought into literature. Texts of contemporary literature provide ample material for researchers to study how the issue of the linguistic identity finds its way in poetry. On the other hand, in this part of the paper, we seek to determine what makes a literary work truly Scottish and whether it is only the language that matters most in this respect. For the study of these issues, our choice has stopped on several contemporary Scottish poets, who pen their work both in English and Scots.

W.N. Herbert, who was born in Dundee, but spent his student years at Oxford and currently is a professor at Newcastle University, pens his work in both English and Scots and states that English is not an "either/or situation" for his work. As he notes: "I do not want to choose between them (English and Scots); I want both prongs of the fork. Are not we constantly hopping registers like? socially-challenged crickets? My motto is And not Or" [3].

He considers himself a "polystylist, obsessed by how different modes of writing interact — not just Scots or English, but also formal or free verse, poetry on the page or in performance, long poems, forty-line lyrics. Everything's a dialect" [4].

The poet has also mentioned that "Scots is a language capable of doing more than English, capable of doing something different from English that criticizes and, ultimately, extends English. That is the spirit in which I write Scots poetry" [5]. What is obvious is that, for Herbert, the status of Scots is not an end in itself. His position with respect to the language policy in Scotland can be discerned in his "Can't Spell, Won't Spell" poem published in The Thing That Mattered Most: Scottish Poems for Children in 2016. The poem deals with the ambiguity and distrust towards the efforts of the public authorities aimed at standardisation of Scots. The fact that there is no standardised orthography of Scots and the failure to come up with a unified system of 
spelling has led to the launch of the Scots Spellchecker Programme, 'Canny Scot', which has aroused much concern. By the way, the name of the spellchecker program is a pun involving on one side the meaning of the word "cannie/canny", which means "wise"; "clever" and the homonym "cannae", which means "cannot".

Cannae spell, winnae spell - lay it oan thi line:

when it come tae orthaegraphic skills this laddie disnae shine.

Eh cannae spell 'MaGonnagal', Eh cannae spell 'Renaissence' hoo Eh feel aboot this flaw is becummin raw complaysance.

If Eh cannae spell in English dae Eh huvtae spell in Scots?

Is meh joattur filled wi crosses when thi proablem is wir nots?

Wir not a singul naishun and therr's not a singul tongue: we talk wan wey gin wir aalder and anither if wir young; we talk diffrent in thi Borders than we dae up in thi Broch; wir meenisters talk funny when they skate oan frozen lochs. Huv ye seen hoo Lech Walensa's Roabin Wulliums wi a tash? Huv ye noticed hoo Pat Lally's kinna nippy wi thi cash? Well yi widnae if yir sittan wi yir heid stuck til a screen trehin tae spell oot whit ye think insteid o seyin whit ye mean [6].

The poem reflects the distrust towards the spellchecker program and the efforts to standardise something which can hardly be standardised. The author is quite frank in bringing his arguments: "we are not a single nation, and there is not a single tonguel older and young people speak differently/ the language is different from region to region/ ministers' language is different depending whether they are in the office or outdoors". It can be inferred that the program is not a sufficient tool to standardise the language because of objective factors. With all the diversity and plurality of forms there is no chance for a spellchecker program to differentiate between thoughts and meanings: trehin tae spell oot whit ye think insteid o seyin whit ye mean.

The poem is written in what is known as dense Scots ${ }^{1}$ but entitled in English. The language is a medium which helps bring up a typically Scottish problem and impart the reactions against the problem of the status of Scots, the futility of the efforts to standardize it. We can just as well assume that for W.N. Herbert, the freedom of choice between English and Scots gives him a broader language spectrum and allows him to experiment with the language, thus introducing his voice in poetry.

Similar attitudes are shared by a vast majority of Scottish authors who are inclined to use both Scots and English in their works. For instance, Edinburgh Makar Christine De Luca, who pens her poetry in Shetlandic, a distinctive dia-

${ }^{1}$ The terms "dense" and "thin" Scots were suggested by J.D. McClure (1979) in his classification of the writings in Scots, i.e. how Scottish the text has to be to quality as Scots rather than Scottish Standard English. According to his model, thin Scots contains few Scots words and other Scots features, and dense Scots has significant quantities of Scots lexis, contains orthographic forms, and has Scots grammar and idioms [7]. 
lect of Scots, and English, confesses that at the beginning of her career she wrote in Shetlandic when the location or theme of the poem seemed to fit and the more reflective type of poem she found sensible to write in the wonderfully rich, subtle, pliable English, this was necessary in particular because of the lack of abstract nouns in Shetlandic. However, when she moved to Edinburgh, she read her dialect poetry in Edinburgh literary circles, and it came to her as a big surprise when people told her that though they do not understand the words, they enjoy the sound of the language and it seems that they understand what the poem is about. So this helped the poet to break her personal linguistic barrier and not confine the Shetlandic dialect to parochial and local themes only [8].

On the one hand, it is understandable that the use of dialect in literature is an important factor for the preservation and transmission of a particular culture. Moreover, the poet's penchant for the use of the Scottish tongue or the mixture of English and Scots can be explained by the simple truth that the writer can write and express well only in the vernacular tongue. It will not be out of place to cite W.B. Yeats who lamented the fact that Ireland could not produce such a great poet as Burns simply because of the lack of the Irish writers in their mother tongue: "no man can write well except in the language he has been born and bred to, and no man, as I think becomes perfectly cultivated except through the influence of that language..." [9]. On the other hand, which is of no less importance, the simultaneous use of Scots and English is a means to view the issue of identity via language and highlight the ways of tackling the conflict of linguistic identities. Sometimes the use of English turns into a vehicle for exploring the issue of identity from the outside, the mixing of different voices contributes to the poet's self-understanding and defining where the poet belongs.

Contemporary Scottish poetry provides an ample material for the study of these questions. The dramatic voice of the author, the mixture of languages and dialects make it possible to view a set of poems from a Bakhtinian angle with the help of such notions as dialogism and heteroglossia ${ }^{1}$. This kind of approach enhances a closer study of poems and helps reveal the internal conflict arising at the clash of two linguistic identities.

The clash of linguistic identities is a central theme of many poems by Jackie Kay's poems, an undeviating devotee of Scottish culture and nationalism. Somehow, Kay is also one of those Scottish poets who has undergone estrangement from Scotland and whose poetry, among other issues, dwells upon the issues of Scottishness and identity from a female perspective, by using a powerful

\footnotetext{
${ }^{1}$ It is worth mentioning that Bakhtinian theoretical tools have previously been applied for the study of Burnsian poetry, particularly, notable is D. Morris's "Burns and Heteroglossia" (1987), where, by comparing Burns and Pope, the author comes to the conclusion that the voices Burns incorporates in his verse represent a much wider social range, which extends even to the large illiterate and unliterary audience [10. P. 22]. Morris notes that "the freedom of speech which was one great aim of political revolution in Burns' age receives a largersocial and cultural-meaning in his work. For Burns, speech was itself a metaphor and arena for freedoms which politics cannot assure" [10. P. 23].
} 
dramatic voice and a discernible tendency for the dialogic, expressed through the dramatic conflict of English and Scots voices. "Old Tongue" (2007) by Kay [11] combines the drama and the conflict of voices, which enables us to read the poem from a Bakhtinian angle.

This partially autobiographical poem is written in thin Scots, the prevalence of English being the background for the unveiling of the internal identity conflict involving both psychological and linguistic aspects.

Kay describes the miserable state of an eight-year-old girl forced to move to London, which made her face the loss of the vernacular tongue, as not long after she finds a strange change: I lost my Scottish accent. The poem goes on telling the strange changes that she experiences: My own vowels started to stretch like my bones, the comparison of the stretched vowels with the stretching of bones indicates the physiological change that she is to face and which is no easier than the psychological adaption that awaits her. The change of the location also resulted in the disappearance of the dour (dear) Scottish words (eedyit, dreich, wabbit, crabbit/ stummer, teuchter, heidbanger,/ so you are, so am ur, see you, see ma ma,/ shut yer geggie or I'll gie you the malkie!) as they were ousted while new words marched in: ghastly, awful,/ quite dreadful ...". It is conspicuous that this is not a mechanical shift of the vocabulary as the attitudes towards those new words and things denoted by them also undergo changes: scones said like stones./ Pokey hats into ice cream cones. Scones and pokey hats in the south get associated with stone and ice, hence that loss of the native tongue has entailed a loss of gustatory pleasure.

The second stanza of the poem places us immediately in a context of direct address: Did you ever feel sad when you lost a word,/ did you ever try and call it back/ like calling in the sea? where the speaker's words imply a dialogic or reciprocal exchange, even when actual dialogue is absent.

The last stanza sounds the deep transformation that the girl has undergone on the English soil, as even her cry has lost its Scottish sound: I cried one day with the wrong sound in my mouth. The realization of the deep transformation, which is equal to the loss of one's sense of belonging, makes the yearning for the lost old words even stronger:

Out in the English soil, my old words

buried themselves. It made my mother's blood boil.

I cried one day with the wrong sound in my mouth.

I wanted them back; I wanted my old accent back, my old tongue. My dour soor Scottish tongue.

Sing-songy. I wanted to gie it laldie.

Throughout the poem, the two voices clash and coalesce internally as English and Scots follow one another as the girl mourns and yearns for the old words. This is how the conflict of voices evolves.

We may also follow how the Bakhtinian notion of heteroglossia finds its way in this poem. Heteroglossia "represents the co-existence of socio-ideological 
contradictions between the present and the past, between differing echoes of past, between different socio-ideological groups in the present, between tendencies, schools, circles, and so forth, all given a bodily form" [12]. The change of the native location and the difficulty of accepting the new environment with all the entailing consequences depicts the confrontation of the two realities - the past and the old cannot come in terms with the present, the new; the changes the girl finds in herself which is demonstrated in the mixed use of English and Scots provide the ground for revealing the conflict between linguistic identities with the help of the language itself.

Discussing other poems by Kay, also by Carol Ann Duffy, and many others, it becomes evident that the use of Scots is not a necessary condition in their poetry to touch upon the problems of identity and sense of belonging. W. R. Aitken claims: "There is a tendency for the Scots writer's nationality to make itself felt, even when writing in English" [13].

For instance, in "Something Rhymed" [14], which celebrates the friendship with Scottish novelist Ali Smith, Kay's female perspective on friendship gets intermingled with the love for Scotland. We can observe that female and national selves are subtly brought together in a small piece of text. The naturalistic description of the feelings is achieved through direct references to indigenous, not anglicised toponyms (Tongland Bridge Solway Firth, Big Water of Fleet, Loch Doon, Galloway, Luce Bay, etc), which expands it from a friendship poem into a deeply patriotic melody. The Scottish landscape and nature has a special claim on the author. The combination of friendship and country imparts lyricism, plays a patriotic rhythm, and provides a more intricate variety of experience. The associations of the friend with Scottish realia (glens, cairns, lochs, forest, wild goat, beeswing, freshwater spring, red deer) hints at the self-sufficiency of the author, a Scottish friend is more than a friend, it is closely connected with the feeling of home, and it is her essence: This feeling inside me could never deny me, and this is Nothing old, nothing new, nothing ventured.

Duffy's "Originally" [15], written all in English, again questions the issues of linguistic identity and the sense of belonging. As a young child, Duffy had to move to the south, and this poem tells the despair of having to part with the native land and vernacular tongue:
$<\ldots$. . I remember my tongue
shedding its skin like a snake, my voice
in the classroom sounding just like the rest. Do I only think
I lost a river, culture, speech, sense of first space and the right place? Now, Where do you come from? strangers ask. Originally? And I hesitate.

In the last stanza, Duffy correlates her sense of belonging with the native tongue, which has changed and transformed now. The comparison of the loss of tongue with the snake shedding its skin hints at the naturalness of the process, but this change has not resulted in full adaptation, and hence her voice is not 
assimilated to the new setting, which in turn augments the need of defining her place: my voice/ in the classroom sounding just like the rest. The move to London caused a set of losses: of home, culture, speech and place and not only. She is now confused answering where she comes from "Originally?".

In terms of the reflection of Scots, "Something Rhymed" and "Originally" are written in English. In the first poem, the lack of Scots is supplanted by the numerous references to the Scottish toponyms and realia imaging the sense of belonging, while in the second poem, the author tries to define her place of belonging by recalling her voice. Scottishness is indisputable in both poems, for English is only a medium for reflections from the outside. Scottishness is woven into the text macrolevel, combining the theme, the aim, the tone, and authorial attitude. The sense of belonging seems to be embedded in the messages hidden in between the lines, triggered by the mindset and the individuality of the author.

\section{Scots: Identity, Reputation, Connotations}

Although the topic of identity is well studied, there is always controversy about it, particularly, the controversy caused by the place of language in the concept of identity. Many authors [16] agree that identity without language is unimaginable; and yet language does not necessarily play the central role in a person's understanding of self. This idea is also proved by the results of the survey we conducted in Kostroma State University. One hundred and three students from various backgrounds were asked which languages they spoke on a regular basis and how they would define their national identity. The results showed the direct correlation between language and identity in 46 cases. Therefore, we may draw a conclusion that language might not necessarily be the tool of selfexpression and the ground for self-identification.

In our opinion, Scots can hardly be regarded as an exception, because we may see certain parallels with the language situation in Russia. Scots is spoken locally within a particularly territory; another language is used as official; Scottish people often come from mixed backgrounds. Besides, lack of standardisation prevents Scots from receiving an official status of a regional language (unlike Gaelic). According to the 2011 Census in Scotland, less than one-third of Scottish population reported the ability to speak Scots. At the same time, the question about national identity produced the following results.

$62 \%$ of the total population stated their identity was 'Scottish only'. That proportion varied from $71 \%$ for 10 - to 14 -year-olds to $57 \%$ for 30 - to 34 -yearolds. The second most common response was 'Scottish and British identities only', at $18 \%$. This was highest in the 65 to 74 age group, at $25 \%$.'British identity only' was chosen by $8 \%$ of the population. The highest proportion stating this identity was the 50 to 64 age group (10\%) [17].

These results demonstrate the absence of a clear correlation between language and identity. Despite this, the number of Scottish authors using Scots spelling and writing whole pages in Scots is growing. The traditional explana- 
tion simplifies the understanding of this phenomenon. It is usually thought that Scottish words make the text more expressive and add national colours.

However, this point of view contradicts the contemporary Scottish understanding of national colours. Scottishness as seen by Robert Burns, Walter Scott, and, later, Robert Louis Stevenson, has undergone considerable changes in the past two decades. Many Scottish people, although grateful to Walter Scott for rekindling the interest in Scottish history, doubt whether the whole world should perceive Scotland as the land of haggis and tartan. In spring, many Edinburgh-based newspapers open a discussion on the need in souvenir shops on the Royal Mile. Critics of the shops wonder whether tourists indeed need a "Tartan tat" of Chinese manufacture and argue that Scotland has more to offer. Many people in Scotland seek to avoid association both with the 19th-century images created by Scott, and with the imperial past seen in Victorian, Georgian, and Regency architecture.

Contemporary literature in Scotland has firmly established itself among the new Scottish attractions. Scottish authors have become known outside Scotland. James Robertson, an outstanding contemporary writer, says Scotland is now the country where you can earn your living by writing. He attributes the phenomenon to the revival of political life in Scotland after the country was granted its own Parliament. Proud to be Scottish, he regularly resorts to Scots in his works. The whole passages and chapters in The Testament of Gideon Mack, The Fanatic, And the Land Lay Still are written in Scots with only minor explanations and comments. Yet he admits that it is the use of Scots that was an obstacle for the sales of his books in North America [18]. In these novels, national colours are so obvious that it seems unnecessary to write in Scots at all. We may assume, therefore, that the use of Scots in contemporary Scottish fiction aims at something different from national colours and the atmosphere of Tartan, mountains and bagpipes.

National identity in its rebellious manifestation may be one of the explanations. Liz Lochhead in the preface to the 2009 edition of Mary Queen of Scots Got her Head Chopped Off [19] says that the victory of the Tories in 1987 drove Scotland into a gloomy mood as Margaret Thatcher was strongly opposed by the Scottish electorate. That is why, although the play was not intended as a parallel between the story of Mary and the political situation in 1987, it was clear Scotland had a "need to tell our own stories and find our own language to tell it in" [20. P. x]. Lochhead describes the surge of emotions when the opening lines of the play-Once upon a time there were twa queens on the wan green islandsounded to her natural and accurate, and fitted the voice of Corbie, a character with the pan-Scotland overview. Before translating Tartuffe in 1985, Lochhead did not realise that she was able to communicate in Scots effectively, but in the process of writing, she understood her Scots developed into a rich language she later used to write Mary's lines. The following example illustrates how effective Scots is when Knox speaks to Mary:

MARY. Ye are owersair for me!

She breaks down sobbing. He is astonished, even sorry.

KNOX. Madam, in God's presence 1 swear that I never delightit in the weeping of ony o God's creatures. As I can scarcely staun the tears o my ain wife or 
ma ain young sons when ma ainhaund is forcit to correct them, faur less can I rejoice in the greetin and howlin and bawlin o Yir Majesty. (Act 1, Scene 4)

The thought that Scots served the purpose of writing fiction as effectively as English was well accepted by other Scottish writers. Irvine Welsh and his novels set in Edinburgh, and Glaswegian James Kelman have been using Scots in their fiction. However, this use of Scots had a visible side effect: after Trainspotting by Welsh [20] was published, Scots all over the world earned the reputation of the language spoken by drug-dealers, thugs and other criminals:

He wistakinnaemair notice though. Ah stoaped harassing him, knowing thit ah wisjistwastin ma energy. His silent suffering through withdrawal now seemed so intense that thirwisnaewey that ah could add, even incrementally, tae his misery. 'Mother Superior' wis Johnny Swan; also kent as the White Swan, a dealer whaewis based in Tollcross and covered the Sighthill and WesterHailes schemes. Ah preferred tae score fi Swanney, or his sidekick Raymie, rather than Seeker $n$ the Muirhoose-Leith mob, if ah could.

The characters created by Kelman, who belong to the Glaswegian working class or the homeless, established the reputation of Scots as the language of the poorest layers of society. However, Scots as the language of law, philosophy, literature, schooling was used in Scotland less than 250 years ago, and was discouraged from public use as an attempt to destroy the memory of the Jacobite Risings. This idea of Scots used as an official language is emphasised in the novel The Fanatic by James Robertson [21], where the action takes place in contemporary Edinburgh and the Edinburgh in 1670. The legal discussions concerning the man charged with treason are written in Scots; they imitate the style of real Scottish legal papers of the 17th century. By a skillful combination of English and Scots to describe interrogation in court, the author makes it easier for the contemporary English-speaker reader to understand the text and at the same time creates the effect of the reader's presence among Scots-speaking people:

'John, ye are reckoned a good man, a kindly man,' Mackenzie said. 'Ye take a care over the unhappy persons that ye are responsible for. Did ye have friendly dealings with the panel, Maister Mitchel, when he was kept in the Tolbooth four year syne?'

'Aye, my lord. We'dhae a conversation noo and again.'

'And did ye discuss with him this matter of the shooting at the Archbishop?'

'Aye, my lord.'

'And did he acknowledge the deed to ye?'

'Aye, my lord.'

'And did he ever justify this deed?'

John Vanse looked over to the panel, but Mitchel studiously avoided his eye. Lauder watched them avidly. He thought of what Mitchel had told him on the Bass. Had Vanse ever connected the prisoner of 1674 with the man who had come to visit Major Weir four years before that, claiming to be his son? If he had, or if he did now, would that make him more or less likely to hurt Mitchel? Or would it make no difference at all?

'Did he ever justify this deed to ye?' Mackenzie repeated. 
Vanse was staring at Mitchel, as if a clock or some such mechanism were clicking and whirring in his brain. Then he spoke.

'I mind yince, we spakaboot evil, whit evil was, whether it was frae man or frae Satan. I'dkent aw kinds o men that had come through the Tolbooth, and it wasna clear tae me wi some o them where their badness cam frae. I mind I asked him how he could kill a man in cauldbluid. I mean, a man that hadna done him ill. I asked him how ony man could be pairty tae saewickit an act.'

'And what was his reply?'

Vanse hesitated, looked again at Mitchel.

'He said it wasna in cauldbluid. He said the bluid o the saints was reekin at the cross o Edinburgh.'

The crowd stirred.

Although difficult to read at first, the pages written in Scots soon start showing the complexity and richness of the language and rid the reader of the idea that Scots is a primitive, broken form of English. (It should be mentioned, though, that according to Anne Nihtinen [22], speakers of Scots sometimes use words accent, dialect or slang to describe their native language).

Using Scots in fiction may also be prompted by the ideas of Scottish independence. Hugh MacDiarmid feared almost a century ago that Scottish writers would soon be writing in English and in 1925 produced several poems in Scots as, in his opinion, Scots can be compared with a Dostoevskian debris of ideas. His Scots masterpiece $A$ Drunk Man Looks at the Thistle appeared several years later and was praised by those who found the ideas of Scottish independence attractive. However, MacDiarmid himself found Scots inadequate to the goal of making Scotland known beyond its own territory. He admitted that English is the only language through which Scotland should channel its image and ideas as Scots is not spoken anywhere else. Similar ideas were later expressed by many postcolonial writers: English enabled them to be heard all over the world whereas the use of their mother tongues was limited by the territory where they were spoken.

Edwin Morgan, one of the most outstanding Scottish poets of the 20th century, preferred not to use Scots at all. We may perceive it as a paradox: the poem written by Morgan to celebrate the Opening of Scottish Parliament and carved on the wall in Scottish Parliament was composed neither in Gaelic, nor in Scots, but in English. However, there is no paradox here. The poem, first of all, is an address of the electorate to parliamentarians. People in Scotland ask them to make wise, clever and unbiased decisions. However, the poem addresses not only Scottish politicians. It sounds like a subtle warning to England and it seems that it is directed straight across the road from Scottish Parliament to Holyrood Palace, the official residence of the Queen in Scotland.

Did you want classic columns and predictable pediments? A growl of old Gothic grandeur? A blissfully boring box?

Not here, no thanks! No icon, no IKEA, no iceberg, but curves and caverns, nooks and niches, huddles and heavens, syncopations and surprises. Leave symmetry to the cemetery. But bring together slate and stainless steel, black granite and grey granite, seasoned oak and sycamore, concrete blond and 
smooth as silk - the mix is almost alive - it breathes and beckons - imperial marble it is not! [23].

The ideas of Scottish independence and Scottish identity expressed in And the Land Lay Still (2010) by James Robertson are again worded in English, although, as we have mentioned above, Robertson welcomes the revival of political life and parliamentarism in Scotland and uses Scots regularly in his works. The Testament of Gideon Mack (2006), written mostly in English, includes passages in Scots where the author tells the ancient legends. It seems, therefore, that Scots is not a political tool for Robertson; it is a technique used to travel between the last and the present as he did in The Fanatic.

Scots now seems a powerful literary tool; however, the attitude to Scots in reality may still be as to the language of lower classes. When Jackie Kay performed her functions as Edinburgh Makar, she made a project of putting her poem in Scots "Welcome Wee One" into boxes the Scottish government gives to mothers of newly born babies. This caused controversy among the mothers; one of the arguments against the poem was the low status of Scots in the country.

$\mathrm{O}$ ma darlin wee one

At last you are here in the wurld

And wi' aa your wisdom

Your eenbricht as the stars,

You've filled this hoose with licht,

Yer trusty wee haun, your globe o' a heid,

My cherished yin, my hert's ain!

$\mathrm{O}$ my darlin wee one

The hale wurld welcomes ye:

The muneglowes; the hearth wairms.

Let your life hae luck, health, charm,

Ye are my bonny blessed bairn,

My small miraculous gift.

I never kentluve like this [24].

At the same time, most women criticised the poem for telling them how to feel about their newborns and admitted they do not share the same feelings as they suffer from post-natal depression. That is why the language of the poem might not necessarily be connected with the outrage it caused. A resource however posted comments of mothers. One of the comments clearly states: It's really not representative of 'my scotland'. One more comment runs: I have to say, while well intentioned, the fact that the poem is written in Scots means that it automatically feels exclusive and unwelcoming to those of us mothers in Scotland who are either not Scottish, or don't engage with/ understand Scots. While I enjoy listening to Scots songs or poetry, I would not have found this poem inspirational or soothing in my confused, hormonal state after my LO was born. All that being said, the last line is beautiful - and true [25].

Some more radical comments from other online resources insist that the poem was an attempt to revive Scottish culture - the thing that does not exist [26]. 
Therefore, even from the comments on a well-meant poem to newborns, we can see the division of the Scottish society about using Scots as the language of literature, not the slang of streets. It seems that contemporary Scottish authors may influence this point of view by writing a word, a phrase, a ling, a page in Scots. Gradually and unevenly, Scots may become what it used to be once- the language officially recognised and used. However, it will take a long time.

\section{Conclusion}

Both the linguistic and political situations in Scotland are characterised by complexity and intricacy of the relationships among the parties involved. The analysis of the poetry and prose made for the purpose of the study has shown the scope and scale of the problem. Lack of the official status and a long way to recognition as an official language has reduced Scots to the dubious position between a language and a regional dialect. Even speakers of Scots find it difficult to say whether they consider Scots a "proper" language; the same disagreement in academic circles does not clarify the situation.

The Independence Referendum of 2014 and the pre-referendum campaign by the Scottish National Party gave an unprecedented boost to the popularity of Scots. However, Scots cannot be regarded as a tool used to fight for a political cause. While many authors and poets highlight the importance of the language as part of national identity and emphasise their loyalty to the ideas of Scottish independence through use of Scots or Scotticisms, others resort to Scots in their works exclusively for the purpose of setting the tone and the mood of the narrative, thus following the tradition set by Sir Walter Scott almost two hundred years ago. Some authors avoid using Scots completely, either in the attempt to distance themselves from the "language of lower classes", or, on the contrary, to make Scottish ideas heard beyond Scotland.

All this reflects the complexity of the language situation and the attitude of various groups of population to Scots. Opinions of people who are not engaged in literature and publishing also vary considerably. Identifying themselves as Scots, they, nevertheless, may not see the need of using Scots in many situations.

The future of Scots and its official status, however, does seem to be connected with politics. While voting to remain part of the UK, many people in Scotland did not foresee the Brexit conundrum and the threat it poses to the idea of Scotland as a truly European nation. While the political situation results in the controversy around the search for Scottish identity, Scottish writers and poets remain a powerful force to make Scots popular again so that it can be used as an official language and not an ornamental element in books and shops for tourists.

\section{References}

1. Häcker, M. (1999) Adverbial Clauses in Scots. A Semantic-Syntactic Study. Berlin; New York: Mouton de Gruyter. 
2. Watson, R. (2006) Living with the double tongue: contemporary poetry in Scots The Edinburgh History of Scottish Literature. Vol. 3. Edinburgh: Edinburgh University Press. pp. 163-175.

3. Herbert, W.N. (1994) Forked Tongue. Hexham: Bloodaxe. pp. 5-12.

4. O'Rourke, D. (ed.) (1994) Dream State: New Scottish Poets. Edinburgh: Polygon. p. 144.

5. Kelly, S. (2009) Headshook: Contemporary Novelists and Poets Writing on Scotland's Future. Hachette Scotland. Scotland on Sunday.

6. Herbert, W.L. (2006) Can't Spell, Won't Spell. In: Johnstone, J. (ed.) The Thing that Mattered Most: Scottish Poems for Children. Scottish Poetry Library.

7. McClure, J. (1995) Scots and its Use in Recent Poetry. In: Scots and its Literature. Amsterdam, Philadelphia: J. Benjamins Publishing Co. pp. 171-190

8. De Luca, C. (2010). 'Language and my poetry'. In: Millar, R.M. (ed.) Northern Lights, Northern Words. Aberdeen: Forum for Research on the Languages of Scotland and Ireland. pp. 107-121.

9. Crowley, T. (2000) The Politics of Language in Ireland 1366-1922: A Source Book. London; New York: Routedge.

10. Morris, D. (1987) Burns and Heteroglossia. The Eighteenth Century. 28 (1). pp. 3-27.

11. Kay, J. (2007) Old Tongue. [Online] Available from: https://www.scottishpoetrylibrary.org.uk/poem/old-tongue/.

12. Bakhtin, M.M. (1981) The Dialogic imagination: Four Essays. Austin, TX: University of Texas Press.

13. Aitken, W.R. (ed.) (1982) Introduction. Scottish Literature in English and Scots: A Guide to Information Sources. Detroit: Gale Research Co.

14. Kay, J. (2008) Something Rhymed. [Online] Available from: https://www.scottishpoetrylibrary.org.uk/poem/something-rhymed/.

15. Duffy, C.A. (2004) Originally. [Online] Available from: https://www.scottishpoetrylibrary.org.uk/poem/originally/.

16. Jackson, J. (2014) Introducing Language and Intercultural Communication. Routledge.

17. Scotland's Census. (n.d.) Ethnicity, Identity, Language and Religion. [Online] Available from: https://www.scotlandscensus.gov.uk/ethnicity-identity-language-and-religion. (Accessed: 02.04.2019).

18. Campbell, J. (2010) A Life in Writing: James Robertson. The Guardian. 14th August.

19. Lochhead, L. (2009) Mary Queen of Scots Got Her Head Chopped Off. London: NHB.

20. Welsh, I. (1993) Trainspotting. Secker \& Warburg.

21. Robinson, J. (2001) The Fanatic. Fourth Estate.

22. Nihtinen, A.L. (2005) Scotland's Linguistic Past and Present: Paradoxes and Consequences. [Online] Available from: https://journal.fi/scf/article/view/7411/5763. (Accessed: 02.04.2019).

23. Morgan, E. (2007) A Book of Lives. Carcanet.

24. Kay, J. (2018) Welcome Wee One. [Online] Available from: https://girlwithherheadinabook.co.uk/2018/10/saturday-poem-welcome-wee-one.html

25. Mumsnet. [Online] Available from: https://www.mumsnet.com/Talk/parenting/ 2816834-love-to-know-what-people-think-of-this-poem. (Accessed: 02.04.2019).

26. Smith, I. (2017) Caledonian Culture War. Blood and Porridge. [Online] Available from: https://bloodandporridge.co.uk/wp/?p=7404. (Accessed: 02.04.2019). 


\section{Шотландский в современной прозе и поэзии: проблемы и противоречия М.С. Саркисян, Е.В. Зимина}

Ключевые слова: скотс, современная шотландская литература, язык и политика, шотландское национальное самосознание.

Саркисян M.C., Зимина E.B. Шотландский в современной прозе и поэзии: проблемы и противоречия // Вестн. Том. гос. ун-та. Филология. 2020. № 66. С. 261-275. DOI: $10.17223 / 19986645 / 66 / 14$

В статье обобщаются результаты исследования использования языка скотс в современной шотландской прозе и поэзии. Целью исследования являлось выявление функций текстовых фрагментов, написанных на языке скотс и включённых в тексты, написанные на английском языке. Мы также предприняли попытку понять, чем руководствуются современные шотландские поэты, которые за последние десять лет всё чаще используют скотс для написания стихов. Наша гипотеза строилась на предположении, что существует прямая связь между увеличением числа текстов на скотс и политическим пробуждением страны с конца 1990-х гг. Следовательно, мы предположили, что вышеупомянутая литературная тенденция отражает возрождение интереса к шотландской истории и традициям, а также необходимость в новом образе Шотландии в мире. В исследование мы включили краткий исторический обзор, чтобы продемонстрировать, как этот образ и отношение к языку скотс менялись в течение нескольких веков и привели к нынешней сложной языковой и исторической ситуации. Мы выбрали ряд писателей и поэтов, которые используют скотс в своих работах. Так как число таких авторов постоянно растёт, мы ограничились Макарами Эдинбурга (аналог Поэтов-лауреатов), а также теми, кто получил престижные литературные премии или был выдвинут на них. Для того чтобы уравновесить наше субъективное мнение, сформировавшееся при чтении и анализе текстов на скотс, мы изучили интервью с этими авторами в британских и шотландских газетах, критические обзоры и читательские комментарии в социальных сетях, а также результаты Шотландской переписи населения 2011 г. Полученные нами результаты подтвердили нашу гипотезу лишь частично. Рост числа текстов на скотс действительно связан с ростом политической активности. Однако это не обязательно означает возрождение Шотландского Парламента в 1999 г. и кампанию по подготовке к референдуму о независимости в начале 2000-х гг. Корни явления лежат в 1980-х гг., когда Маргарет Тэтчер была избрана на повторный срок, что вызвало разочарование в Шотландии и побудило многих авторов дистанцироваться от Англии. Что касается нового образа Шотландии и использования скотс для пробуждения чувства национального самосознания, в этом вопросе, по нашим наблюдениям, существует много спорного. Некоторые писатели и поэты действительно рекламируют национальную идею, демонстрируя, как скотс может использоваться в сфере права, религии и истории. Другие используют скотс для создания речи необразованных слоёв населения. Некоторые поэты полагают, что скотс не подходит для того, чтобы представлять новую Шотландию, поскольку использование языка ограничивается территорией самой Шотландии. Исследование показало, что более частое использование скотс в прозе и поэзии, вызванное политическими изменениями, действительно способствует развитию интереса шотландцев к собственным корням. В то же время и авторы и читатели выражают сомнение, должен ли скотс играть ведущую роль в формировании нового образа Шотландии и может ли он возродиться в качестве официального языка. 